\title{
機能水による洗浄の基礎
}

\section{Fundamental of Cleaning by Functional Water}

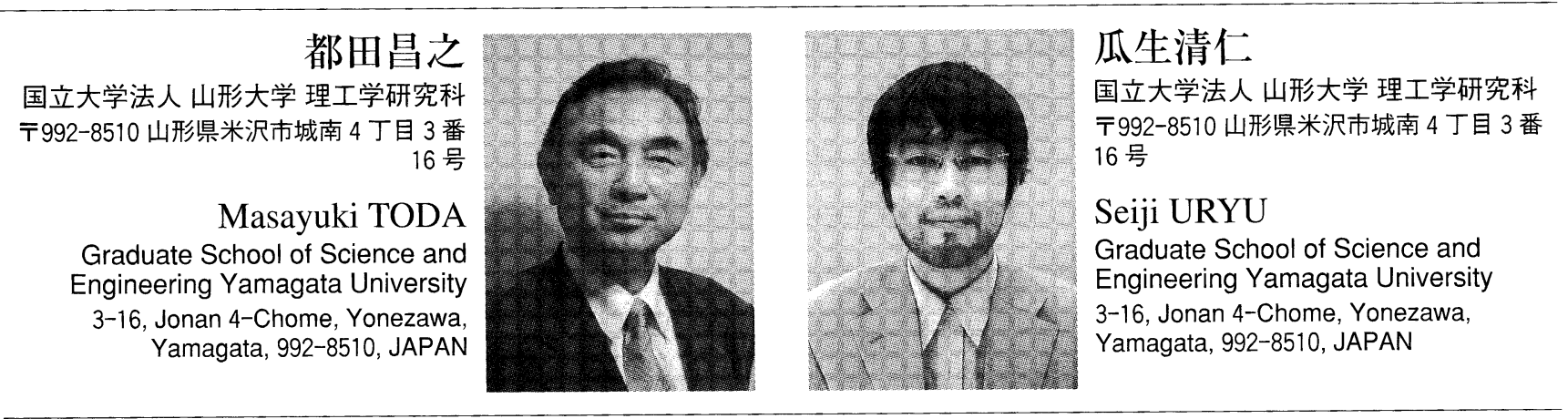

論文要旨：半導体製造工程に扔けるウエハ表面の洗浄は，1970 年に RCA 社の W. Kern らによって提案さ れた RCA 洗浄方法を基盤とする洗浄方法によって行われてきた。 $\mathrm{RCA}$ 洗浄方法は $\mathrm{H}_{2} \mathrm{O}_{2}$ をべースに $\mathrm{H}_{2} \mathrm{SO}_{4}$, $\mathrm{NH}_{4} \mathrm{OH}, \mathrm{HCl}$ などの薬液を混合し, 高温にて洗浄を行う回分操作である。このため, 薬液蒸気によるクリー ンルームの活染やウエハ表面に残存する薬液をリンスするために必要な超純水の使用量の増大などの問題が 生じた。これらの問題を解決するため新しい洗浄方法が提案された。この方法においては，超純水や薬液の 使用量が少なく，また，超音波励起水やオゾン水などの機能水も利用されている。現在，機能水と呼ばれる 水は幅広く存在し，それによる洗浄方法も要求される分野によって多種多様である。ここでは, 機能水によ る洗浄の基礎ともいえる機能水の特性についてその一部を概説する。

Abstract: The cleaning of wafer surface in the semiconductor manufacturing process has been carried out on the basis of RCA cleaning procedure proposed by W. Kern et al in 1970. This method uses the cleaning solutions prepared by the respectively mixing of sulfuric acid, ammonia, hydrochloric acid, etc on the basis of hydrogen peroxide, and it is a batch cleaning process in relatively high temperature. Therefore, the problems such as the contamination by chemical vapor in the clean room and the increase of ultra pure water necessary for the rinse of chemicals on wafer surface occurred. The new cleaning procedure was proposed in order to solve the above-mentioned problems. In this method, the consumption volumes of ultra pure water and chemicals are very small, and also the functional water such as ultrasonic wave excitation water, ozonized water and so on are utilized. At the present time, a lot of water called as the functional water widely exists, and there are so many cleaning methods by the functional water in the required fields.

In the present paper, some part of the functional water which is fundamental to cleaning by functional water will be explained briefly.

Key words: Dilute Chemical, Functional Water, Hydroxide Radical, RCA Cleaning Solution, Hydrogen Peroxide, Ultra Sonic Wave, Ultraviolet Rays, Ozonized Water, Super Critical Water

\section{1 はじめに}

半導体製造工程におけるウエハ表面の洗浄は 1970 年 にW. Kern ${ }^{1)}$ が提唱したRCA 洗浄方法をもとに行われ てきた。この方法は, 過酸化水素をベースに硫酸, アン モニア，塩酸などの薬液を混合し，高温にて洗浄を行う バッチ式である。このため, 薬液の蒸気によるクリーン
ルーム内の污染，薬液のすすぎのために必要な超純水の 使用量の増加などの問題が生じる。これらの問題を解決

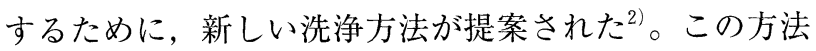
では超純水や薬液の使用量が極めて少なく ${ }^{3)}$, 超音波励 起水やオゾン水などの機能水も利用されている。ここで は機能水による洗浄の基礎ともいえる機能水 ${ }^{4)}$ の特性に ついてその一部を概説することにする。 


\section{2 機能水の基盤となる水の構造}

水分子は分子内で分極している。このため, 酸素原子 は $\delta$-で水素原子は $\delta+$ となっている。この分極が水の 特異な性質を示すことになる。これにより水分子間の水 素と酸素の間に緩い結合, 即ち水素結合が発生する。こ の性質のため，水は何分子かで集団（クラスター）を形 成している。電気分解水ではクラスターの数は 6 個以 下，カルシウム添加水では 6 個以上の水分子からクラス ターは構成される。水道水ではその数は大凡 13 個程度 である。また，水は空隙が多くその值は $50 \%$ といわ れる ${ }^{4)}$ 。水の中には空間があるが，その平均的なホール の大きさは $5 \AA$ 程度である ${ }^{5)}$ 。

\section{3 超純水を基盤とする機能水の特性}

「機能水」とは，水分子そのものがその形を変えずに 固有な役割を果たすものではなく，水溶液中の構成因子 がそれぞれ固有な役割を果たすものである。

\section{$3 \cdot 1 \mathrm{RCA}$ 洗浄水}

デバイスの特性や性能に影響を及ぼすウエハ表面污染 物の対象は，表面に物理的に，または，化学的に吸着し たサブミクロンのパーティクル，重金属不純物，微量な 有機不純物そして自然酸化膜などである。これらを短時 間に除去する方法の一つに 1970 年に RCA 社の W. Kern らによって提案された洗浄方法1) はあまりにも有名であ る。それは過酸化水素を基盤とし硫酸, フッ酸, アンモ ニア, 塩酸などの薬品および超純水を使用して効果的に ウエ八表面を洗浄するものである。このプロセスでは,

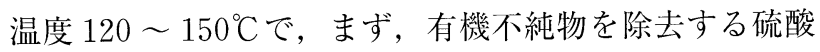
と過酸化水素の混合液（SPM）が用いられる。次いで, 酸化膜を除去するために希フッ酸が使用される。その 後, $\mathrm{SC} 1$ と称される温度 $80 \sim 90^{\circ} \mathrm{C}$ のアンモニア・過酸
化水素・水の混合液 (APM) によってパーティクルが 除去され，そして SC2 と呼ばれる温度 $80 \sim 90^{\circ} \mathrm{C}$ の塩 酸・過酸化水素・水の混合溶液 (HPM) で金属不純物 が除去される。最後に, 希フッ酸によって酸化膜を除去 するものである。この他ウエハ表面をリンスするため超 純水 (UPW) が使用される。これは工程中で数百回も 繰り返され，その使用量は 6 インチウエハ 1 枚当たり約 $5 \sim 7 \mathrm{t}$ ともいわれている。表面を超高清浄に保つため に必要な超純水の量ではあるがすさまじい使用量であ る。

\section{$3 \cdot 2$ 超音波励起水}

ウエハ表面洗浄について, 近年, 新たな洗浄方法が提 案された2)。これには超音波も導入されている。

Fig. 1 に超音波照射による超純水の比抵抗の変化を示 す。超純水中の酸素量 $\left(\mathrm{DO}_{2}\right) 8.75 \mathrm{ppm}$, 窒素量 $\left(\mathrm{DN}_{2}\right)$ $17.13 \mathrm{ppm}$ の場合, 超音波照射後, 比抵抗は大きく減少

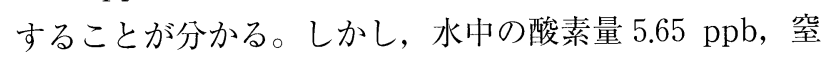
素量 $2.60 \mathrm{ppm}$ の場合，超音波照射によって比抵抗は大 きく変化しない。これは前者の場合, 超音波照射により 水中にラジカルが生成し, そのラジカルと溶存ガスが反 応しイオン種を生成するためである。

Fig. 2 に超音波を照射した場合の各種溶存ガスによる ラジカル生成の違いを示す。酸素や窒素が溶存する場合 $\mathrm{OH}$ ラジカルの生成が多い。アルゴン或いは窒素を溶解 させた水に超音波照射して得たイオン種を Fig. 3 に示 す。イオン種として $\mathrm{NH}_{4}{ }^{+}, \mathrm{NO}_{2}{ }^{-}, \mathrm{NO}_{3}{ }^{-}$が見られ，そ の量はアルゴン溶解の場合がいずれのイオン種において も多い。過酸化水素の生成はアルゴン溶解の場合が多 い。すなわち, 超音波照射によるラジカル生成は溶存ガ スおよびその量に影響されることが分かる。

\section{$3 \cdot 3$ 紫外線照射水}

使用した UV ランプの波長は $185 〜 546 \mathrm{~nm}$ と 254〜

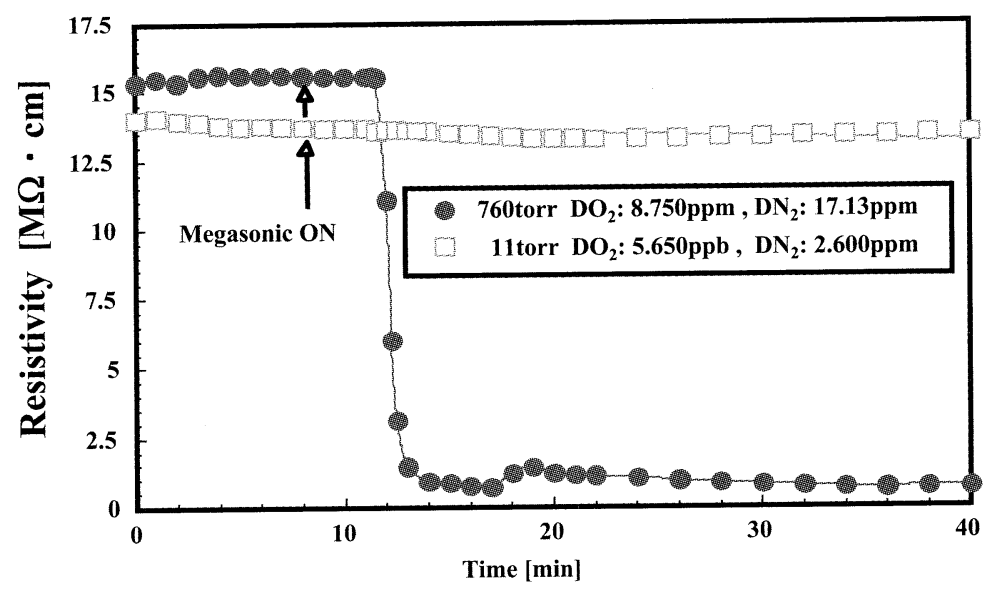

Fig. 1 Variation of Resistivity of Ultra Pure Water with Megasonic Irradiation. 


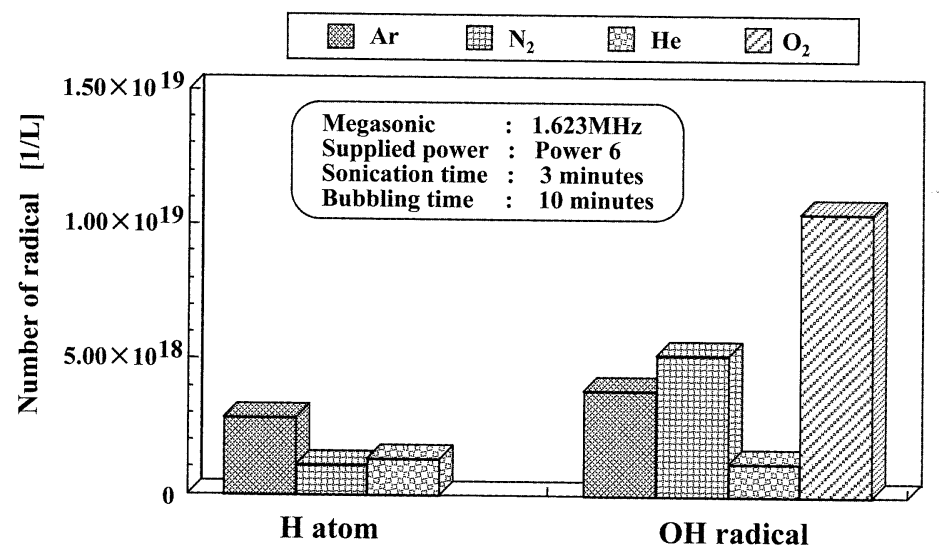

Fig. 2 Effect of Dissolved Gas on H Atom and OH Radical Formation.

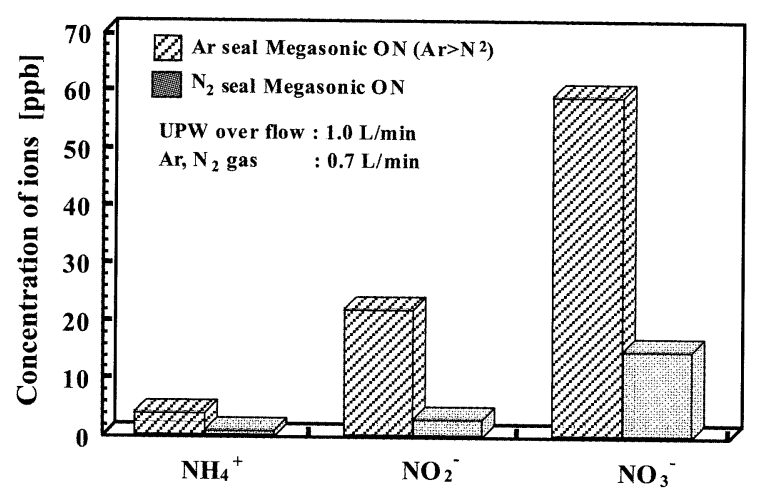

Fig. 3 Effect of Dissolved Gas on Ion Formation.

$546 \mathrm{~nm}$ である。サンプルは空気飽和水を 30 Torr まで 脱気し, 酸素, 窒素, 水素, アルゴンをそれぞれ溶解さ せた水である。ラジカルの確認にはスピントラッピング 剂の DMPO（5,5-dimetyl-1-pyrroline-N-oxyl）が用い られた にラジカルの生成は認められない。酸素, 窒素, アルゴ
ン，水素をそれぞれ溶解した水に 254 ～ $546 \mathrm{~nm}$ の光照 射を行ってもラジカルの生成は認められない。しかし， 波長 185 ～ $546 \mathrm{~nm}$ の UV 照射を行うとラジカルの生成 が確認される。したがって，水分子の $\mathrm{O}-\mathrm{H}$ 結合を切断 する波長は $185 \mathrm{~nm}$ であると理解される。

Fig. 4 は, UV および超音波（周波数： $0.95 \mathrm{MHz}$, 出 力： 278 W）をそれぞれ 4 分間照射した後のラジカル生 成量を比較して示したものである。UVランプの波長は 185 〜 $546 \mathrm{~nm}$ である。超音波照射の場合には見られな い $\mathrm{H}$ 原子の生成が水素水に UV 照射した場合に確認さ れる。また，超音波照射の場合と比較すると溶存ガスの 種類によってラジカルの生成量に違いがみられる。ま た, Fig. 4 には水素飽和水にアンモニアを添加し, 超音 波照射した場合のラジカル生成の様子も示されている。 アンモニアを添加することでラジカルの生成が促進され ることが理解される。

\section{$3 \cdot 4$ 電解イオン水}

フッ素系カチオン交換膜を用い, アノードおよびカ

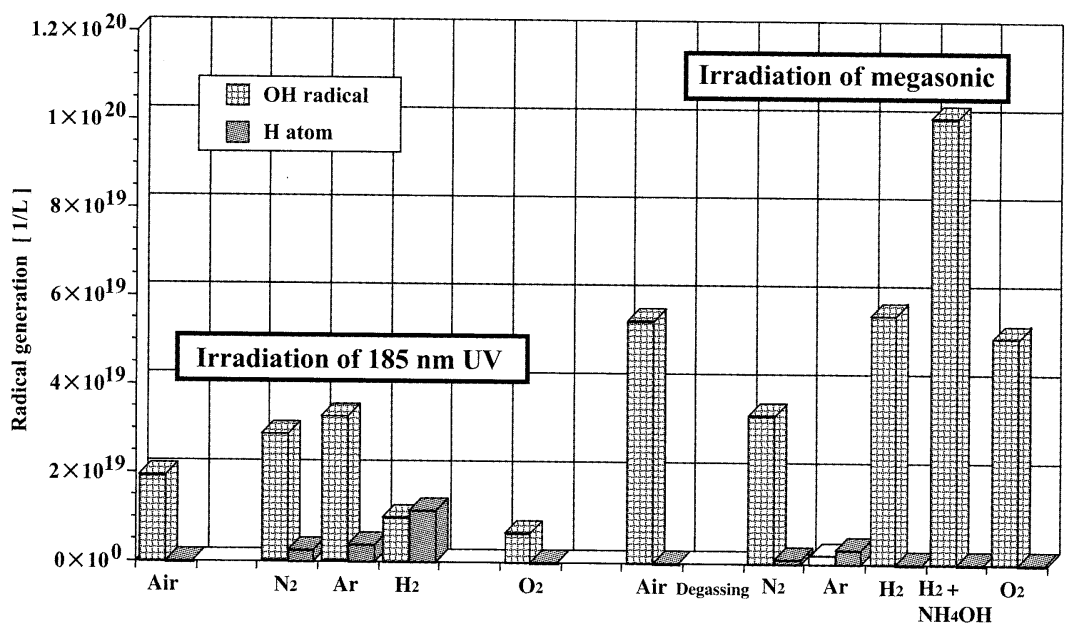

Fig. 4 Comparison of Radical Generation by 4 Minutes Irradiation of $185 \mathrm{~nm}$ UV and Megasonic. 
ソード電極にPtを使用し, 超純水を電流密度 $20 \mathrm{~mA}$ $\mathrm{cm}^{2}$ 以下で電解処理すると，アノードには酸素が，ま た，カソードには水素が発生する。その溶液の $\mathrm{pH}$ は 7 で，反応は以下のとおりである。

$$
\text { アノード反応 : } 2 \mathrm{H}_{2} \mathrm{O}-4 \mathrm{e} \Rightarrow 4 \mathrm{H}^{+}+\mathrm{O}_{2}
$$$$
\text { カソード反応 : } 4 \mathrm{H}^{+}+4 \mathrm{e} \Rightarrow 2 \mathrm{H}_{2}
$$

しかし，電流密度を上げるか，または，アノード電極 に $\beta-\mathrm{PbO}_{2}$ を用い電解するとアノード側にオゾンの生成 が認められようになる。反応は以下のと抢りである。

$$
\begin{aligned}
& \text { アノード反応 : } 3 \mathrm{H}_{2} \mathrm{O}-6 \mathrm{e} \Rightarrow 6 \mathrm{H}^{+}+\mathrm{O}_{3} \\
& \text { アノード反応 : } \mathrm{H}_{2} \mathrm{O}+\mathrm{O}_{2}-2 \mathrm{e} \Rightarrow 2 \mathrm{H}^{+}+\mathrm{O}_{3} \\
& \text { カソード反応 : } 4 \mathrm{H}^{+}+4 \mathrm{e} \Rightarrow 2 \mathrm{H}_{2}
\end{aligned}
$$

生成された新たな物質がウエハなど固体表面の洗浄に効 果を現すことになる。また，数百 $\mathrm{ppm}$ の $\mathrm{NH}_{4} \mathrm{OH}$ を添 加した水を電解して得た電解カソード水はアルカリ性で 強い還元性を示す。還元性の発現は生成される $\mathrm{H}_{2}$ によ るものである。一方, 数百 $\mathrm{ppm}$ の $\mathrm{HCl}$ を添加した水を 電解して得られる電解アノード水は酸性で強い酸化性を 示す。この酸化性の発現は生成する $\mathrm{O}_{3}$ や $\mathrm{ClO}_{X}$ によるも のである。さて, 薬液使用量の極めて少ない電解イオン 水がウエハ洗浄プロセスへ応用された場合，これまで $\mathrm{RCA}$ 洗浄において使われている薬品使用量をどの程度 低減できるであろうか。 $100 \mathrm{~m}^{3} / \mathrm{hr}$ の超純水を使用する 月産 60,000 枚の 6 インチウエハを処理する工場を例に

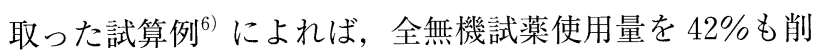
減できる。さらに，電解イオン水を洗浄プロセスに採用 することによって薬品使用量やリンス用超純水の大幅な 削減が期待されることも分かった。

\section{5 水素溶解水}

水素水は直接水素ガスを超純水に溶解することによっ ても，また，電解イオン水のカソード水として得られる 水溶液にも水素が溶解している。水素は還元性の強い気 体であり，ウエ八表面の水素終端（ウエ八表面に位置す る $\mathrm{Si}$ を水素 $\mathrm{H}$ で覆い尽くす，すなわち，表面を $\mathrm{SiH}$ と するのである）にも利用できる。

Fig. 5 は，各種洗浄液を用いた微粒子除去に関する既 往の研究成果である。いずれの洗浄溶液に対しても超音 波が重畺されており，溶液内には $\mathrm{OH}$ ラジカルの生成が 見られるものと推察される。水素水にアンモニアを添加 した洗浄水が最も微粒子を除去する能力の高いことは明 らかである。これは超音波照射により多くの $\mathrm{OH}$ ラジカ ルが生成され，これによって溶液内に過酸化水素が生成

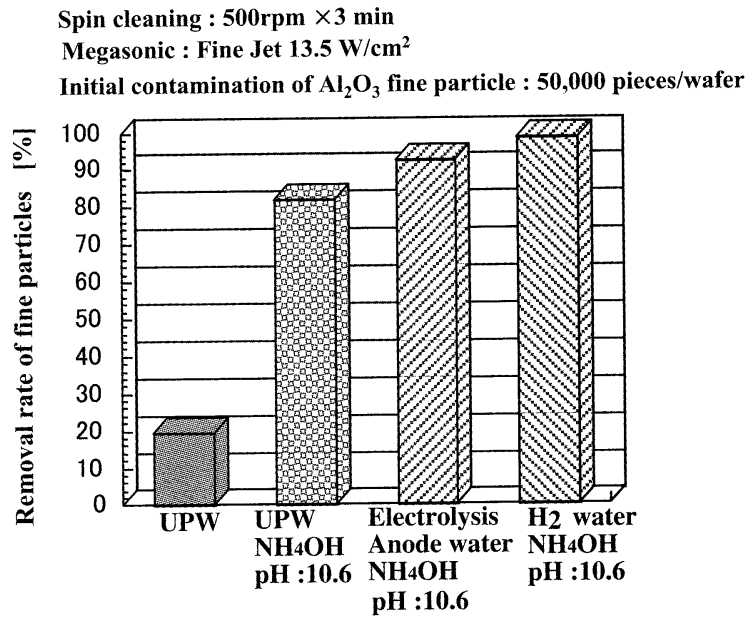

Fig. 5 Comparison of Particle Removal Using Various Cleaning Solutions.

される。この過酸化水素とアンモニアの組合せ（APM 溶液）で微粒子が良く除去されるのである。

\section{$3 \cdot 6$ オゾン溶解水}

炭酸ガスをわずかに含む $\mathrm{pH}=5.35$ 〜 5.5 の水に，才ゾ ンを $20 \mathrm{ppm}$ ほど溶解させると溶液の $\mathrm{pH}$ は 4.5 程度に まで低下する。水に溶解したオゾンは, 水中の $\mathrm{OH}^{-}$か ら電子を引き抜くと同時に, 酸素原子ラジカルと酸素分 子に分裂する。酸素原子ラジカルは, 水と反応して過酸 化水素 $\mathrm{H}_{2} \mathrm{O}_{2}$ を生成する。あるいは生成した酸素原子ラ ジカル同士が結合して酸素分子を生成するであろう。こ れにより溶液の $\mathrm{OH}^{-}$イオンが減少し, $\mathrm{H}^{+}$イオンが増加 することになり溶液は酸性を示す。溶存オゾンの減少に ついては各研究者によって研究成果も異なる。Weiss ${ }^{8)}$, Alder ${ }^{9)}$ によるとオゾンは水中で自己分解し, 酸素と水 を生成すると報告されている。それぞれの反応モデルを Fig. 6 に示す。Fig. 6 に示される $\mathrm{OH}$ ラジカルは, オゾ ンにも勝る強力な酸化力をもつため, 物質の表面洗浄に 直接的に関与している可能性がある。この $\mathrm{OH}$ ラジカル 生成はオゾン水をアルカリ性や中性に調整したものでは

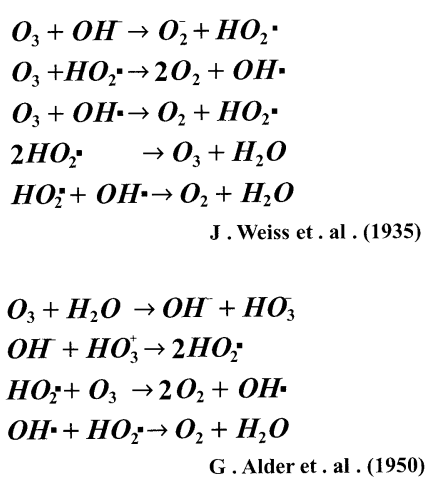

Fig. 6 Decomposition Reaction of Ozone. 


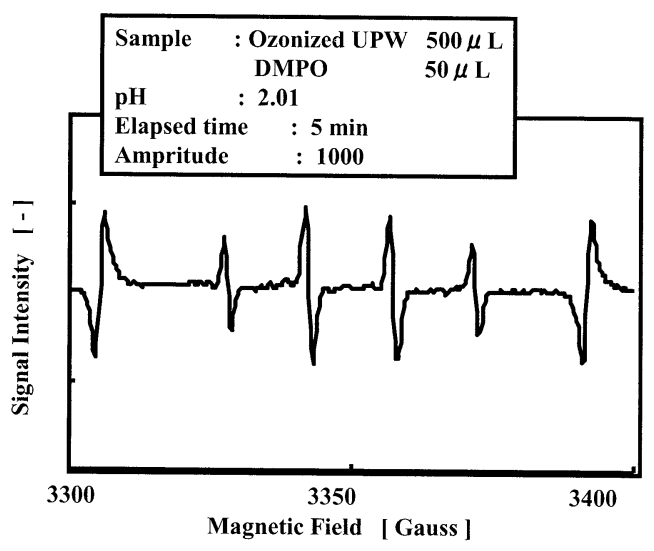

Fig. 7 Radical Generation in Acidic Ozonized Water.

認められない。しかし， pHを 2 に調整したオゾン水中 には, Fig. 7 に示すようにラジカルの生成が確認される。 その生成要因はオゾンの自己分解によるもの以上に過酸 化水素と水素イオンが鉄イオンを触媒として反応し, $\mathrm{OH}$ ラジカルを生成する Harber-Weiss 反応によるもの が支配的である。鉄イオン $\left(10^{15} \sim 10^{16}[\right.$ atoms $\left./ \mathrm{L}]\right)$ の 混入は半導体製造ラインで使用する薬液に含まれる不純 物である。さらにオゾン水中の酸素やプロトンの存在が 金属溶解の決め手である ${ }^{10)}$ 。

\section{$3 \cdot 7$ 低溶存酸素水}

酸素がわずかに溶解した室温，あるいは，温超純水に はウエハ表面に物理吸着した金属を溶解させる機能があ る。この場合, 液中にプロトンが存在することが必要不 可欠である。Fig. 8 は銅の丸棒を超純水に炭酸ガスと酸 素を溶解させた水溶液に浸漬し金属銅の溶解量を示した ものである。炭酸ガスは水と反応し $\mathrm{H}^{+}$イオンを生成す るので, 炭酸ガスは一種のプロトン供与体と考えられ る。話は変わるが, 窒素で飽和された超純水から溶解ガ

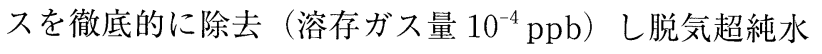

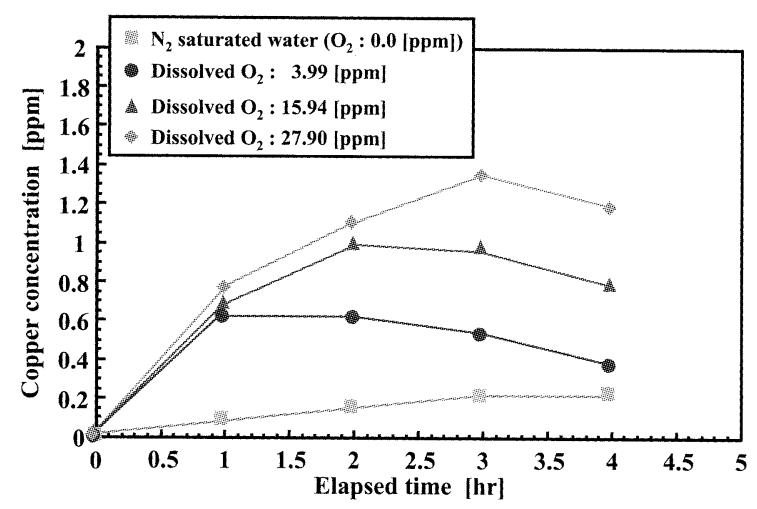

Fig. 8 Dissolution of $\mathrm{Cu}$ into $\mathrm{N}_{2}$ Water Containing Dissolved $\mathrm{O}_{2}$ $\left(\mathrm{CO}_{2}\right.$ concentration : $\left.9.74[\mathrm{ppm}]\right)$
を作成した。脱気超純水はお腹のすいた水，いわゆる， ハングリーウォータであろうと想像されるが実際にはな かなか気体を吸収しない液体であることが分かった。む しろわずかに気体を含む超純水の方がいち早く気体を吸 収することが確認されている11)。また，脱気すると超音 波の伝達も悪くなりラジカル生成も認められない。しか し, 脱気水は溶解ガス制御水を製造する上に必要であ る。

\section{$3 \cdot 8$ 超臨界水}

物質の状態は一般的には固体, 液体, 気体の 3 つであ るが，条件によってはもう一つの状態が存在する。物質 をある温度，ある圧力以上にすると，液体や気体とは まったく性質の異なる流体が得られる。この時の温度, 圧力をそれぞれ臨界温度 Tc, 臨界圧力 Pc, まとめて臨 界点と呼び，ここの物質に対して固有な值となる。水の Tc，Pcの值はそれぞれ $374.25^{\circ} \mathrm{C}, 218.3 \mathrm{~atm}$ である。

一般に, 臨界温度, 臨界圧力を越えた領域が「超臨 界」領域であり，この領域にある水を超臨界水と呼ぶ。 超臨界水は，われわれが日常慣れ親しんでいる液体の水 や気体の水蒸気とは著しくかけ離れた特異な性質を示 す。超臨界水の特異な性質として, 通常の化学反応速度 を律速している溶解度, 粘性, 熱伝達率, 拡散速度, 誘 電率等などが通常の液体状態の場合と異なるのみなら ず，温度または圧力の変動によって大幅に変化させるこ とができる。これらの特性を利用して超臨界流体を化学 反応系の溶媒として，または，反応物質そのものとして 使用すれば，既存の化学反応プロセスの大幅な簡素化， 省力化, 省資源化, 無公害化といった面での役割と効果 は大きいものと考えられる。たとえば，常温・常圧の水 には約 $8 \mathrm{ppm}$ の酸素しか溶解しないため，有機物を完 全に酸化分解して無害化するためには強力な酸化剂（薬 液）を使用する必要があり，反応時間も長時間となる。 ところが, 超臨界水はもともと高温流体であることに加 え, 任意の量の酸素を溶解できるため, 超臨界水のみで 極めて短時間に有機物を完全に酸化分解することができ る。また，窒素含有量の高い有機物の燃焼においても反 応条件を適切に設定すれば，ほとんど $\mathrm{NO}_{x}$ を排出させ ずに完全然焼させることもできるのである。

\section{4 おわりに}

現在, 半導体ウエハ洗浄方法は $\mathrm{RCA}$ 洗浄から超純水 を基本洗浄液とした新しい洗浄プロセスへの転換期を迎 えている。以下に本概説を通して得られた $2 \sim 3$ の知見 を示す。

(1) 水に超音波を照射することでイオン種や過酸化水 素が生成する。その生成は溶存ガスによって影響され 
る。溶存空気を $10^{-4} \mathrm{ppb}$ まで脱気した脱気超純水に超音 波を照射してもラジカルの生成は見られない。超音波を 用いる洗浄法では RCA 洗浄法と同様, 活性なラジカル $\mathrm{OH}$ が生成されることから $\mathrm{RCA}$ 洗浄法に替わる洗浄法 である。

(2)オゾン水を低 $\mathrm{pH}$ にすると $\mathrm{OH}$ ラジカルの生成は 促進される。

（3）紫外線照射では水をラジカル活性にする光の波長 は $185 \mathrm{~nm}$ より短いものが有効である。254 nmより大 きい波長の紫外線は水分子の水素と酸素の結合を切断す る程のエネルギではないことが示された。しかし，当然 ながら光触媒（たとえば， $\mathrm{TiO}_{2}$ など）を浮遊させるこ とによりラジカルを生成できる。

\section{文献}

1) W. Kern \& D.A. Puotien, RCA Review, 31, 187 (1970).

2) 大見忠弘：第 25 回超 LSI ウルトラクリーンテクノロ ジーシンポジウム, UCS 半導体基盤技術研究会 pp. 1932.

3) K. Kubo, S. Ojima, M. Toda \& T. Ohmi, Extended abstracts of 188 th Electrochemical Society Meeting, 710 (1995).

4）都田昌之他，初歩から学ぶ機能水，工業調査会 (2002).

5）上平 恒，水とはなにか，講談社 (1991).

6) K. Yamashita, et al., Clean Technol., 7 (4), 47 (1997).

7) 桜井 弘, ESR スペクトルの実際, 廣川書店 (1989)。

8) J. Weiss, Trans. Faraday Soc., 31, 668 (1935).

9) G.A. Alder \& G.R. Hill, J. Am. Chem. Soc., 72, 1884 (1950).

10）阿久戸和哉，修士学位論文，山形大学 (2001).

11) 加藤正行, 修士学位論文, 山形大学 (1995). 